\title{
Comparative Study on Caesarian and Normal Delivery Childbirth in Bangladesh
}

\author{
Md. Shohel Rana*, Md. Rasel Hossain, Nilufa Aktar, Kabir Hossain, Bashirul Alam, Asma-Ul-Hosna \\ Department of Statistics, Noakhali Science and Technology University, Noakhali, Bangladesh \\ Email: *rana.nstu83@gmail.com
}

How to cite this paper: Rana, Md.S., Hossain, Md.R., Aktar, N., Hossain, K., Alam, B. and Asma-Ul-Hosna (2021) Comparative Study on Caesarian and Normal Delivery Childbirth in Bangladesh. Open Journal of Statistics, 11, 524-538.

https://doi.org/10.4236/ojs.2021.114033

Received: June 12, 2021

Accepted: August 16, 2021

Published: August 19, 2021

Copyright $\odot 2021$ by author(s) and Scientific Research Publishing Inc. This work is licensed under the Creative Commons Attribution International License (CC BY 4.0).

http://creativecommons.org/licenses/by/4.0/

\begin{abstract}
The study is concerned with caesarian and normal delivery and its effectiveness on childbirth which has more impact on Bangladesh. We identified that, higher educated and higher income families are choosing caesarian section for childbirth because of improved safety of surgical skill to reduce the mortality rate. Although expensive, most caesarian operations are performed in private hospitals for modern medical equipment, experienced doctors and advanced medical care. A questionnaire survey design was applied in order to make a comparative study on caesarian and normal delivery childbirth. Respondents from all over Bangladesh participated in the survey. We collect 281 data from the respondents of different districts of Bangladesh by area sampling. We use descriptive and analytical research designs in determining the comparative study on caesarian and normal delivery childbirth in Bangladesh. The results of study show that the variance of children taken by caesarian delivery is less than children taken by normal delivery and children taken by caesarian delivery increase due to increased family income. It has been found that $39.5 \%$ (111) respondents are from the Urban area and $60.5 \%$ (171) from the rural zone. We can say that more than $50 \%$ of our respondents are well-educated. We also found that $53.4 \%$ of the respondents do not face any problem in $\mathrm{C} / \mathrm{S}$. We found that family income has a positive linear relationship with the $\mathrm{C}$-section deliveries, which means that higher incoming people tend to have the $\mathrm{C}$-section more. Finally, we observed that change in rate of caesarian delivery due to changing living places and normal delivery is recommended for the next generation. By Meta analysis we found that number of cesarean delivery baby is independent of locality and education level.
\end{abstract}

\section{Keywords}

Caesarian Delivery, Normal Delivery, Operation, Meta Analysis 


\section{Introduction}

Generally considered safe, caesarian section does have more risk than caesarian births. Plus moms can go home sooner and recover quicker after normal delivery but improve safety of surgical skills to reduce the mortality rate in caesarian delivery.

Cesarean delivery is a surgical intervention designed to prevent or treat life-threatening maternal or fetal complications. The World Health Organization (WHO) estimated that about $5 \%-15 \%$ of pregnancies would face life-threatening complications. When it is done on a timely basis, cesarean delivery provides a golden opportunity to prevent the adverse obstetric outcomes, including maternal death, stillbirth and nearly neonatal death, obstetric fistula, uterine prolapsed and sexual dissatisfaction [1]. Amount of death due to pregnancy is gradually decreasing worldwide, among all of these estimated deaths, one-fifth of the maternal deaths are recorded in southern Asia [2]. Delivery may occur either by caesarean or non-caesarean. Multiple factors associated with safe delivery practices, range from demographic to socio-economic. More than $70 \%$ of the deliveries took place at home, and only $32 \%$ of birth in Bangladesh were under safe and hygienic conditions. In recent years, caesarean delivery is one of the most common surgical procedures. Caesarean sections (C-section) are more common among first births (12.7\%), births in urban areas (15.9\%), and especially among births in the private sector (67.3\%), whereas the public sector was $34.6 \%$. The number of caesarean delivery has also been growing in many developed and developing countries and this increase has not been clinically justified. Over the last few years, the rates of C-section have risen substantially in many countries such as Brazil (30\%), Chile (40\%), the USA (24.4\%) and Malaysia (15.7\%). According to $\mathrm{WHO}$, there is no justification for any region to have a caesarean rate higher than 10 - 15 [3].

Bangladesh has achieved remarkable success in improving maternal and child health. The majority (79\%) of Bangladeshi women now receive antenatal care and $36 \%$ receive postnatal care. In 2014 , overall $37 \%$ of births were delivered to informal healthcare facilities including $22 \%$ births in private facilities, of which staggering $61 \%$ and $77 \%$ of births ended in CS, respectively. A number of factors may influence this increasing rate of CS in Bangladesh, including high rate of adolescent pregnancy (35\%), increasing rate of late aged pregnancy (5\%), improving educational and socio-economic status of mothers, and the ongoing dual nutritional burden (co-existing conditions of under and over nutrition) [4].

\subsection{What Is Caesarian Delivery?}

Caesarean section, also known as C-section, or caesarean delivery, is the surgical procedure by which a baby is delivered through an incision in the mother's abdomen, often performed because vaginal delivery would put the baby or mother at risk [5]. 


\subsection{What Is Normal Delivery?}

A vaginal delivery is the birth of offspring in mammals through the vagina. It is the natural method of birth for all mammals except monotremes, which lay eggs. For humans, the average length of a hospital stay for a normal vaginal delivery is 36 - 48 hours. Surgery extends that stay [5].

\section{Background of the Study}

Amount of childbirth by caesarian are gradually increasing worldwide. The increasing rate of caesarian delivery than normal delivery because of improved safety of surgical skill to reduce pregnancy related mortality (Md. Iftakhar Parvej, Preferences between Caesarean Section and Normal Vaginal Delivery among the reproductive women in Bangladesh, 2021) [2]. In Bangladesh, the CS rate has increased more than eight-fold, from $2.7 \%$ in 2000 to $24 \%$ in 2014 (Mohammad Masudur Rahman, 2018) [6]. In the past few decades, a number of maternal health related strategies were adopted and implemented by the government of Bangladesh. Natural childbirth is in general, very safe but it becomes risky when a woman ignores her health care provider's recommendation. This study concludes that the overall fetomaternal outcome is better in caesarean section than the patients who underwent vaginal delivery (M Khandoker, 2020) [7]. Negative effects of caesarian section \& normal delivery on childbirth cause countless infant deaths each year in the world. The place (Government clinic or Private clinic) of caesarian operation used to find out the attitude of public and private hospitals in childbirth.

Caesarian delivery known as $\mathrm{C}$-section is a surgical operation which is safer than normal delivery when the baby condition isn't progressing/in distress/in abnormal position/problem with placenta. The process has now become most popular all over the world. In developing countries, like Bangladesh has also a significant role to give birth healthy baby. Maternal mortality rate decreased than that before by C-section. But it has more risk than normal delivery. Like tummy pain, abnormal vaginal discharge, heavy vaginal bleeding, blood clot in leg etc. Bangladesh Government has established Community Clinic (cc) to give births by normal delivery. In cc the number of normal deliveries conducted at $246.80 \%$ to $128,36.26 \%$ in 2012 to 2016 [8]. In Dhaka the cost of normal delivery average is $1275 \mathrm{tk}, 4703 \mathrm{tk}$ in C-section where the monthly income of family is 4933 tk. That means every family bears the cost of $95.34 \%$ of their family income per C-section cost [9]. In 2004-2016 the rate of C-section increases from $4 \%$ to $31 \%$. In 2016-2018 the rate is 51\%. In 2018 the parents of Bangladesh paid $\$ 483$ million cost for C-section which is medically unnecessary [10]. One of the major problems in modern health system is uncontrolled increase of caesarean section. This study examines the association of reported complications around delivery and socio-demographic, healthcare and spatial characteristics of mothers with CS.

\section{Objectives}

1) To know the pattern of caesarian and normal delivery of childbirth in Ban- 
gladesh.

2) To determine the influential factor of caesarian and normal delivery.

3) To make a comparative study between caesarian and normal delivery.

4) To determine the family income effect on caesarian and normal delivery childbirth in BD.

\section{Methodology}

\subsection{Data Collection}

We have collected the data by questionnaire method from all over the country by cluster sampling. The students of first year of the department of statistics, they are involved to collect the data from each of the selected cluster (district) of the country cover. We did collect 281 of total respondents those who are targeted population by our study.

\subsection{Methods}

The paper used descriptive and analytical research designs in determining the comparative study on caesarian and normal delivery childbirth in Bangladesh. Different types of graph were used to show the pattern of caesarian and normal delivery childbirth. Chi-square test and Pearson Correlation were applied to find out the significant relationship between study variables. Finally, Binary Logistic Regression was used to establish the effect of the independent variables on the dependent variable and Meta analysis used to find out the independent of number of cesarean delivery baby in locality and education level. The data were analyzed by using Statistical Package for the Social Sciences (SPSS) version 25.0.

\section{Ethics Statement}

We have committed to the respondent in questionnaire that the information which they have provided is very confidential and we have to use this data only research purpose not unethical purpose. All respondents that did consent use this information in study purpose only. For this reason, it did not need any approval from IRB. The data were analyzed anonymously.

\section{Result and Discussion}

Table 1 represents the frequency and percentage for all questionnaire variables according to their classification.

From the descriptive statistics Table 2, the variance of children taken by caesarian delivery is less than children taken by normal delivery. So we conclude that caesarian delivery is better than normal delivery childbirth.

Table 3 indicates, there is weekly linear relationship between family income and children taken by caesarian delivery with a positive slope that means increase caesarian delivery due to increase family income. Also weekly linear relationship occurs between family income and children taken by normal delivery 
Table 1. Frequency and percentage for all study variables according to their classification.

\begin{tabular}{|c|c|c|c|}
\hline Variables & Classification & Frequency & Percentage (\%) \\
\hline \multirow{2}{*}{ Gender of respondent } & Male & 2 & 0.7 \\
\hline & Female & 279 & 99.3 \\
\hline \multirow{2}{*}{ Where you from } & Urban & 111 & 39.5 \\
\hline & Rural & 170 & 60.5 \\
\hline \multirow{5}{*}{ Educational qualification } & Illiterate & 12 & 4.3 \\
\hline & Primary & 33 & 11.7 \\
\hline & Secondary & 95 & 33.8 \\
\hline & Higher-secondary & 71 & 25.3 \\
\hline & Graduation & 70 & 24.9 \\
\hline \multirow{2}{*}{ How many children do you have } & $1-3$ & 252 & 89.7 \\
\hline & $4-6$ & 29 & 10.3 \\
\hline \multirow{2}{*}{ Children taken by caesarian } & $0-2$ & 262 & 93.2 \\
\hline & $3-4$ & 19 & 6.8 \\
\hline \multirow{3}{*}{$\begin{array}{l}\text { How many children } \\
\text { taken by normal delivery }\end{array}$} & $0-2$ & 246 & 87.5 \\
\hline & $3-4$ & 33 & 11.7 \\
\hline & $5-6$ & 2 & 0.7 \\
\hline \multirow{5}{*}{ Family income per month } & $5000-25,000$ & 127 & 45.2 \\
\hline & $26,000-45,000$ & 91 & 32.4 \\
\hline & $46,000-65,000$ & 37 & 13.2 \\
\hline & $66,000-85,000$ & 07 & 2.5 \\
\hline & $>86,000$ & 19 & 6.8 \\
\hline \multirow{3}{*}{ Cost of caesarian } & $0-25,000$ & 208 & 74.0 \\
\hline & $26,000-45,000$ & 67 & 23.8 \\
\hline & $>46,000$ & 06 & 2.1 \\
\hline \multirow{2}{*}{ Cost in normal delivery } & $1000-5000$ & 219 & 77.9 \\
\hline & $6000-10,000$ & 62 & 22.1 \\
\hline \multirow{2}{*}{ Place of caesarian delivery } & Govt clinic & 121 & 43.1 \\
\hline & Private clinic & 160 & 56.9 \\
\hline \multirow{2}{*}{$\begin{array}{l}\text { Do you face any problem } \\
\text { by caesarian delivery }\end{array}$} & Yes & 132 & 46.6 \\
\hline & No & 149 & 53.4 \\
\hline Recommendation & Caesarian & 55 & 19.6 \\
\hline for the next generation & Normal & 226 & 80.4 \\
\hline
\end{tabular}

Table 2. Descriptive statistics of some important variables.

\begin{tabular}{lcccccc}
\hline \multicolumn{7}{c}{ Descriptive Statistics } \\
\multicolumn{1}{c}{ variable } & $\mathrm{N}$ & Minimum & Maximum & Mean & Std. Deviation & Variance \\
\hline gender of respondent & 281 & 1.00 & 2.00 & 1.9929 & 0.08421 & 0.007 \\
where you from & 281 & 1.00 & 2.00 & 1.6050 & 0.48973 & 0.240 \\
education qualification & 281 & 1.00 & 5.00 & 3.5480 & 1.11420 & 1.241 \\
how many children do you have & 281 & 1.00 & 2.00 & 1.1032 & 0.30477 & 0.093 \\
children taken by cesarean & 281 & 1.00 & 2.00 & 1.0676 & 0.25153 & 0.063 \\
how many children taken by & 281 & 1.00 & 3.00 & 1.1317 & 0.35921 & 0.129 \\
normal delivery & & & & & & \\
\hline
\end{tabular}




\section{Continued}

\begin{tabular}{|c|c|c|c|c|c|c|}
\hline family income per month & 281 & 1.00 & 5.00 & 1.9324 & 1.13659 & 1.292 \\
\hline cost of cesarean & 281 & 1.00 & 3.00 & 1.2811 & 0.49566 & 0.246 \\
\hline cost in normal delivery & 281 & 1.00 & 2.00 & 1.2206 & 0.41542 & 0.173 \\
\hline place of cesarean delivery & 281 & 1.00 & 2.00 & 1.5694 & 0.49604 & 0.246 \\
\hline $\begin{array}{l}\text { do you face any problem by } \\
\text { cesarean delivery }\end{array}$ & 281 & 1.00 & 2.00 & 1.6690 & 1.71362 & 2.937 \\
\hline $\begin{array}{l}\text { recommendation for next } \\
\text { generation }\end{array}$ & 281 & 1.00 & 2.00 & 1.8043 & 0.39747 & 0.158 \\
\hline Valid N (listwise) & 281 & & & & & \\
\hline
\end{tabular}

Table 3. Correlation between normal delivery children and cesarean delivery children with family income.

\begin{tabular}{|c|c|c|c|c|}
\hline \multicolumn{5}{|c|}{ Correlations } \\
\hline & & $\begin{array}{l}\text { children taken } \\
\text { by caesarian }\end{array}$ & $\begin{array}{l}\text { how many children taken } \\
\text { by normal delivery }\end{array}$ & $\begin{array}{l}\text { family income } \\
\text { per month }\end{array}$ \\
\hline \multirow{3}{*}{$\begin{array}{l}\text { children taken } \\
\text { by caesarian }\end{array}$} & Pearson Correlation & 1 & -0.020 & 0.029 \\
\hline & Sig. (2-tailed) & & 0.741 & 0.634 \\
\hline & $\mathrm{N}$ & 281 & 281 & 281 \\
\hline \multirow{3}{*}{$\begin{array}{l}\text { how many } \\
\text { children taken by } \\
\text { normal delivery }\end{array}$} & Pearson Correlation & -0.020 & 1 & -0.039 \\
\hline & Sig. (2-tailed) & 0.741 & & 0.511 \\
\hline & $\mathrm{N}$ & 281 & 281 & 281 \\
\hline \multirow{3}{*}{$\begin{array}{l}\text { family income per } \\
\text { month }\end{array}$} & Pearson Correlation & 0.029 & -0.039 & 1 \\
\hline & Sig. (2-tailed) & 0.634 & 0.511 & \\
\hline & $\mathrm{N}$ & 281 & 281 & 281 \\
\hline
\end{tabular}

with a negative slope, that means decrease normal delivery due to increase family income.

Table 4 means, there is weekly linear relationship between parent's educational qualification and children taken by caesarian delivery with a positive slope that means increase caesarian delivery due to increase educational qualification and significant relationship with each other. On the other hand there are very weekly relationship educational qualification and normal delivery.

Table 5 shows that the facing problem in caesarian delivery is weakly correlated with recommendation for next generation significantly.

Table 6 means place of living is weakly correlated with both caesarian and normal delivery.

\section{Regression analysis}

The model is significant. The fitted regression model for those variables. Caesarian delivery $=1.008+0.037$ * Living place. The slope 0.037 represents change of rate of caesarian delivery due to changing living places (Table 7). 
Table 4. Correlation of cesarean delivery and normal delivery with educational qualification.

\begin{tabular}{|c|c|c|c|c|}
\hline \multicolumn{5}{|c|}{ Correlations } \\
\hline \multirow{2}{*}{ variable } & & \multicolumn{2}{|c|}{ children taken how many children taken } & \multirow{2}{*}{$\begin{array}{l}\text { education } \\
\text { qualification }\end{array}$} \\
\hline & & by cesarean & by normal delivery & \\
\hline \multirow{3}{*}{$\begin{array}{l}\text { children taken } \\
\text { by cesarean }\end{array}$} & Pearson Correlation & 1 & -0.020 & $0.135^{\star}$ \\
\hline & Sig. (2-tailed) & & 0.741 & 0.024 \\
\hline & $\mathrm{N}$ & 281 & 281 & 281 \\
\hline \multirow{3}{*}{$\begin{array}{c}\text { how many children } \\
\text { taken by normal } \\
\text { delivery }\end{array}$} & Pearson Correlation & -0.020 & 1 & -0.038 \\
\hline & Sig. (2-tailed) & 0.741 & & 0.524 \\
\hline & $\mathrm{N}$ & 281 & 281 & 281 \\
\hline \multirow{3}{*}{$\begin{array}{l}\text { education } \\
\text { qualification }\end{array}$} & Pearson Correlation & $0.135^{*}$ & -0.038 & 1 \\
\hline & Sig. (2-tailed) & 0.024 & 0.524 & \\
\hline & $\mathrm{N}$ & 281 & 281 & 281 \\
\hline
\end{tabular}

Table 5. Correlation of cesarean delivery and normal delivery with recommendation for the next generation.

\begin{tabular}{cccc}
\hline \multicolumn{3}{c}{ Correlations } & \\
\hline $\begin{array}{c}\text { do you face any } \\
\text { problem by cesarean } \\
\text { delivery }\end{array}$ & Pearson Correlation & $\begin{array}{c}\text { do you face any problem } \\
\text { by cesarean delivery }\end{array}$ & $\begin{array}{c}\text { recommendation } \\
\text { for next generation }\end{array}$ \\
\hline $\begin{array}{c}\text { Sig. (2-tailed) } \\
\text { next generation }\end{array}$ & $\mathrm{N}$ & 1 & 0.030 \\
recommendation for & Sig. (2-tailed) & 281 & 0.612 \\
& $\mathrm{~N}$ & 0.030 & 1 \\
\hline
\end{tabular}

Table 6. Correlation between residual and delivery process.

\begin{tabular}{|c|c|c|c|c|}
\hline \multicolumn{5}{|c|}{ Correlations } \\
\hline & & where you from & $\begin{array}{l}\text { children taken } \\
\text { by caesarian }\end{array}$ & $\begin{array}{c}\text { how many children } \\
\text { taken by normal } \\
\text { delivery }\end{array}$ \\
\hline \multirow{3}{*}{ where you from } & Pearson Correlation & 1 & 0.073 & 0.033 \\
\hline & Sig. (2-tailed) & & 0.225 & 0.584 \\
\hline & $\mathrm{N}$ & 281 & 281 & 281 \\
\hline \multirow{3}{*}{$\begin{array}{l}\text { children taken } \\
\text { by caesarian }\end{array}$} & Pearson Correlation & 0.073 & 1 & -0.020 \\
\hline & Sig. (2-tailed) & 0.225 & & 0.741 \\
\hline & $\mathrm{N}$ & 281 & 281 & 281 \\
\hline how many & Pearson Correlation & 0.033 & -0.020 & 1 \\
\hline children taken & Sig. (2-tailed) & 0.584 & 0.741 & \\
\hline by normal delivery & $\mathrm{N}$ & 281 & 281 & 281 \\
\hline
\end{tabular}




\section{Chi-square test}

This Chi-square test indicates the face problem in cesarean delivery and recommendation for next generation is significantly correlated (Table 8).

Cross tabulation analysis

The Chi-square test shows the place of cesarean delivery and facing problem is highly significant (Table 9).

\section{Graphical representation}

About $61 \%$ people live in urban area and 39\% people live in rural area (Figure 1).

Figure 2 indicates about $87.5 \%$ women have 0 - 2 children, $11.7 \%$ women have 3 - 4 children and $0.7 \%$ women have 5 - 6 children in their family.

Table 7. Regression analysis of children taken by cesarean on place of residence.

\begin{tabular}{|c|c|c|c|c|c|c|c|c|c|c|c|}
\hline \multicolumn{12}{|c|}{ Coefficients $^{\mathrm{a}}$} \\
\hline \multirow{2}{*}{\multicolumn{2}{|c|}{ Model }} & \multicolumn{2}{|c|}{$\begin{array}{l}\text { Unstandardized } \\
\text { Coefficients }\end{array}$} & \multirow{2}{*}{$\begin{array}{c}\begin{array}{c}\text { Standardized } \\
\text { Coefficients }\end{array} \\
\text { Beta }\end{array}$} & \multirow[t]{2}{*}{$\mathrm{t}$} & \multirow{2}{*}{ Sig. } & \multicolumn{2}{|c|}{$\begin{array}{l}\text { 95\% Confidence } \\
\text { Interval for B }\end{array}$} & \multicolumn{3}{|c|}{ Correlations } \\
\hline & & B & Std. Error & & & & Lower Bound & Upper Bound & Zero-order & Partial & Part \\
\hline 1 & (Constant) & 1.008 & 0.051 & & 19.585 & 0.000 & 0.906 & 1.109 & & & \\
\hline
\end{tabular}

${ }^{a}$ Dependent Variable: children taken by cesarean.

Table 8. Cross tabulation analysis.

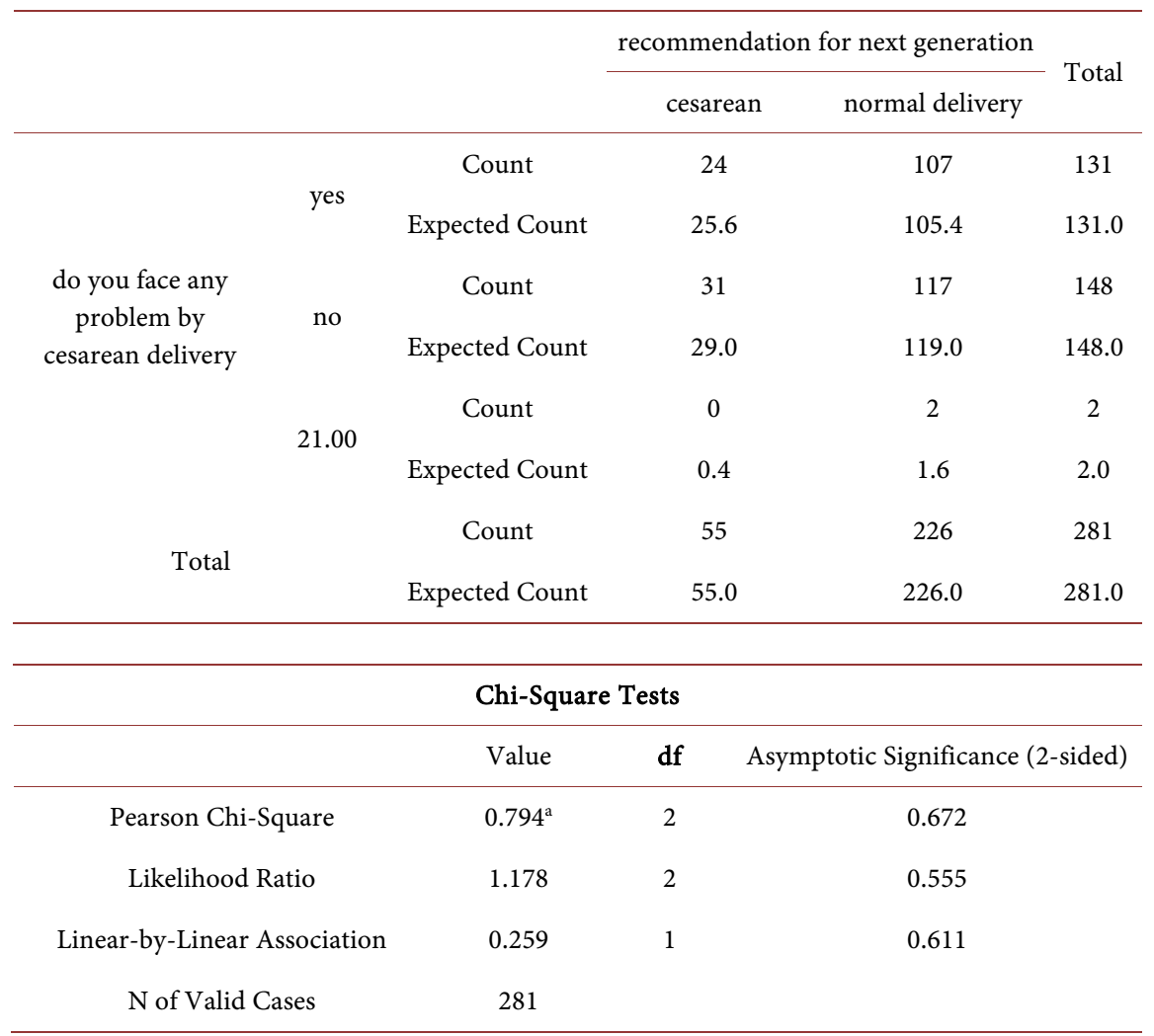

a2 cells (33.3\%) have expected count less than 5 . The minimum expected count is 0.39 . 
Table 9. Cross tabulation analysis.

\begin{tabular}{|c|c|c|c|c|c|c|}
\hline & & & \multicolumn{3}{|c|}{$\begin{array}{l}\text { Do you face any problem } \\
\text { by cesarean delivery }\end{array}$} & \multirow[t]{2}{*}{ Total } \\
\hline & & & yes & no & 21.00 & \\
\hline \multirow{4}{*}{$\begin{array}{c}\text { Place of } \\
\text { cesarean delivery }\end{array}$} & \multirow{2}{*}{ Govt. clinic } & Count & 60 & 60 & 1 & 121 \\
\hline & & Expected Count & 56.4 & 63.7 & 0.9 & 121.0 \\
\hline & \multirow{2}{*}{ Private } & Count & 71 & 88 & 1 & 160 \\
\hline & & Expected Count & 74.6 & 84.3 & 1.1 & 160.0 \\
\hline \multirow{2}{*}{\multicolumn{2}{|c|}{ Total }} & Count & 131 & 148 & 2 & 281 \\
\hline & & Expected Count & 131.0 & 148.0 & 2.0 & 281.0 \\
\hline \multicolumn{7}{|c|}{ Chi-Square Tests } \\
\hline & & Value & df & \multicolumn{3}{|c|}{ Asymptotic Significance (2-sided) } \\
\hline Pearson Chi & -Square & $0.824^{\mathrm{a}}$ & 2 & \multicolumn{3}{|c|}{0.662} \\
\hline Likelihood & Ratio & 0.824 & 2 & \multicolumn{3}{|c|}{0.662} \\
\hline Linear-by-Linear & Association & 0.004 & 1 & \multicolumn{3}{|c|}{0.947} \\
\hline $\mathrm{N}$ of Valid & Cases & 281 & & & & \\
\hline
\end{tabular}

${ }^{a} 2$ cells (33.3\%) have expected count less than 5 . The minimum expected count is 0.86 .

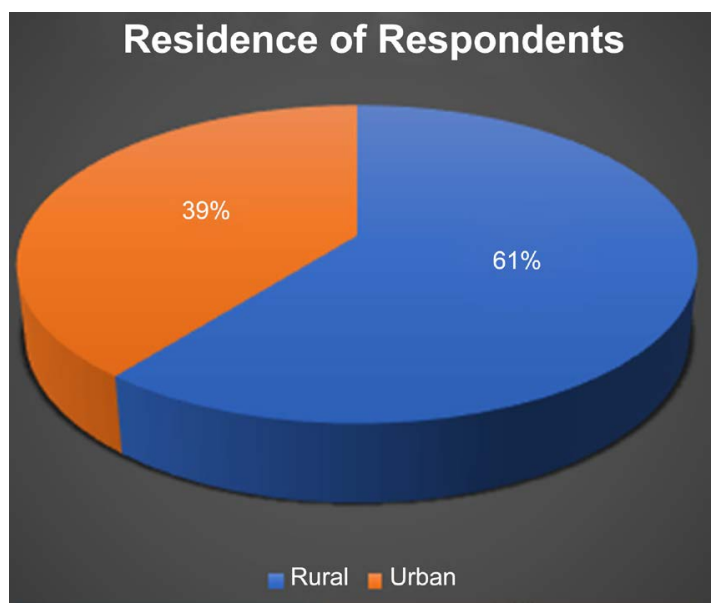

Figure 1. Pie diagram of place of residence.

\section{How many children taken by normal delivery}

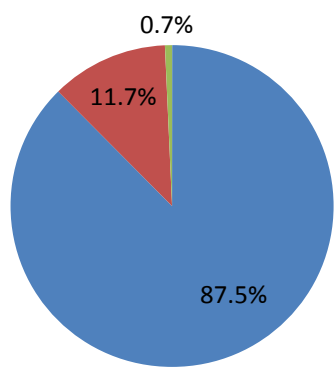

Figure 2. Pie diagram of children taken by normal delivery. 
Figure 3 indicates 25\% respondents who have passed their graduation, 25\% passed higher-secondary, $34 \%$ passed secondary, $12 \%$ passed primary and $4 \%$ illiterate during the study.

Figure 4 presents percentage of place of caesarian delivery.

Maximum caesarian delivery about 53\% occurs in private clinic (Figure 5).

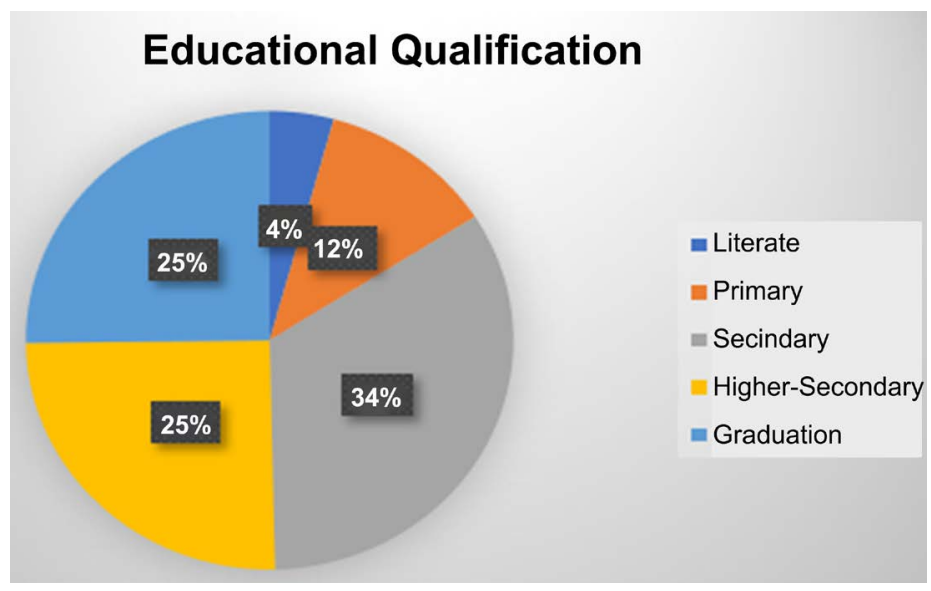

Figure 3. Percentage of educational qualification of respondent (Women).

\section{PRESENTING OF CAESARIAN \& NORMAL DELIVERY}

를 Series 1

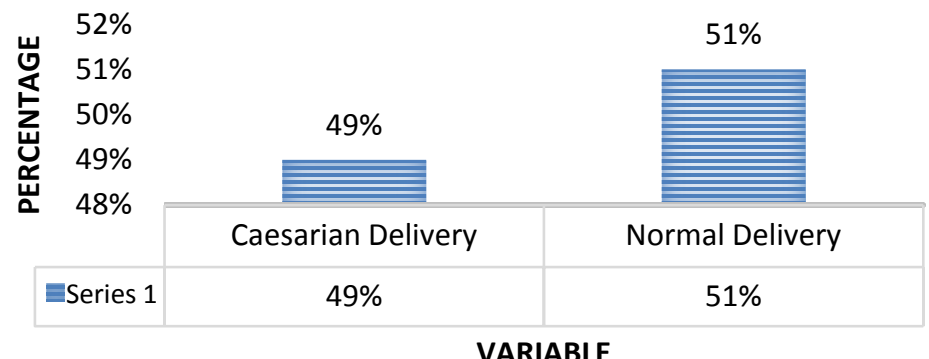

VARIABLE

Figure 4. Percentage of caesarian and normal delivery.

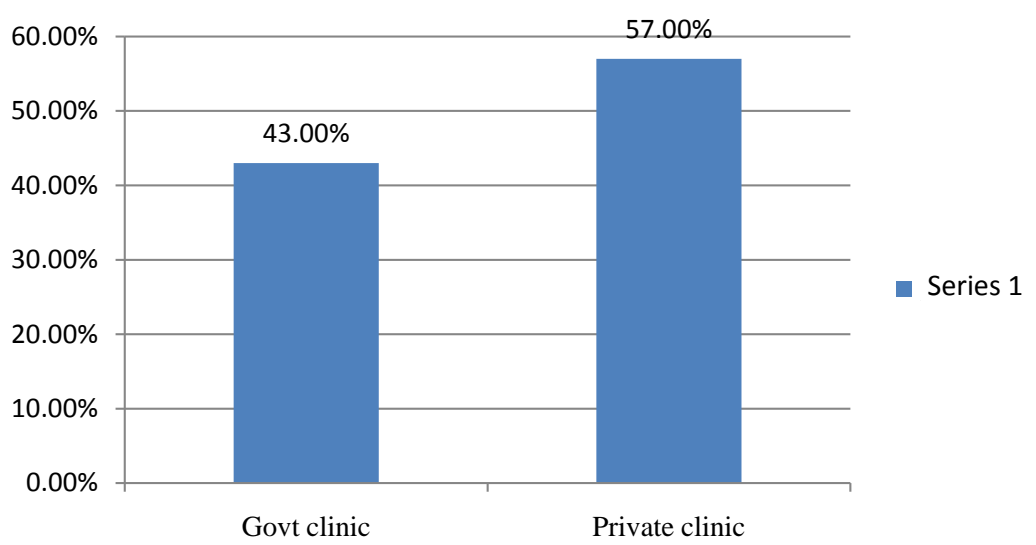

Figure 5. Percentage of place of caesarian delivery. 
Figure 6 is positive trend that means normal delivery is recommended for next generation.

Binary Logistic regression analysis

This means, $27 \%$ people are facing problem in caesarian delivery in government clinic and $84 \%$ urban people are facing problem in caesarian delivery. $99 \%$ primary educated people are facing problem in caesarian delivery and $32 \%$ graduated people are facing problem in caesarian delivery. $45 \%$ people are taken baby by caesarian delivery and facing problem (Table 10).

Binary logistic regression Table 11 shows, 59\% secondary educated people and $51 \%$ higher educated people are recommended caesarian delivery for the next generation. And $72 \%$ people who are taken children by caesarian delivery

\section{Recommendation for the next generation}

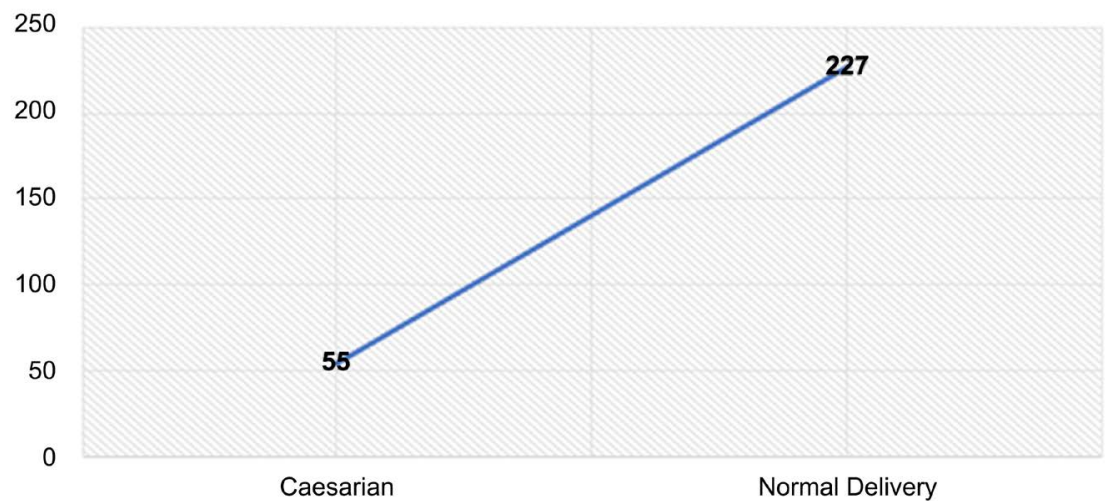

Figure 6. Recommended for next generation.

Table 10. Binary Logistic regression analysis of some significant variables.

\begin{tabular}{|c|c|c|c|c|c|c|c|c|c|}
\hline \multicolumn{10}{|c|}{ Variables in the Equation } \\
\hline & & \multirow[b]{2}{*}{$\mathrm{B}$} & \multirow{2}{*}{ S.E. } & \multirow[b]{2}{*}{ Wald } & \multirow[b]{2}{*}{$\mathrm{df}$} & \multirow[b]{2}{*}{ Sig. } & \multirow{2}{*}{$\operatorname{Exp}(B)$} & \multicolumn{2}{|c|}{ 95\% C.I. for $\operatorname{EXP}(B)$} \\
\hline & & & & & & & & Lower & Upper \\
\hline & place of caesarian delivery (1) & 0.242 & 0.252 & 0.925 & 1 & 0.336 & 1.274 & 0.778 & 2.089 \\
\hline & where you from (1) & 0.614 & 0.252 & 5.938 & 1 & 0.015 & 1.847 & 1.128 & 3.025 \\
\hline & education qualification & & & 0.653 & 4 & 0.957 & & & \\
\hline & education qualification (1) & -0.006 & 0.688 & 0.000 & 1 & 0.993 & 0.994 & 0.258 & 3.830 \\
\hline & education qualification (2) & 0.158 & 0.627 & 0.064 & 1 & 0.801 & 1.171 & 0.343 & 3.999 \\
\hline \multirow[t]{6}{*}{ Step $1^{\mathrm{a}}$} & education qualification (3) & 0.062 & 0.642 & 0.009 & 1 & 0.923 & 1.064 & 0.302 & 3.743 \\
\hline & education qualification (4) & 0.281 & 0.641 & 0.192 & 1 & 0.661 & 1.324 & 0.377 & 4.656 \\
\hline & how many children do you have & -0.342 & 0.412 & 0.690 & 1 & 0.406 & 0.710 & 0.317 & 1.593 \\
\hline & children taken by caesarian & 0.372 & 0.511 & 0.531 & 1 & 0.466 & 1.451 & 0.533 & 3.951 \\
\hline & cost of caesarian & -0.301 & 0.251 & 1.435 & 1 & 0.231 & 0.740 & 0.452 & 1.211 \\
\hline & constant & -0.171 & 0.914 & 0.035 & 1 & 0.851 & 0.842 & & \\
\hline
\end{tabular}

${ }^{a}$ Variable(s) entered on step 1: place of caesarian delivery, where you from, education qualification, how many children do you have, children taken by caesarian, cost of caesarian. 
recommended caesarian delivery for the next generation. $61 \%$ people recommended government clinic for caesarian delivery. The people who spend $54 \%$ for caesarian delivery are recommended caesarian delivery (Table 11).

\section{Meta analysis}

Let us consider, $\mathrm{H}_{0}$ : Number of cesarean baby independent of location and education level (Table 12).

$\mathrm{H}_{1}$ : Number of cesarean baby depends on location and education level.

We conduct the test at $5 \%$ level of significance.

Test statistics:

Table 11. Binary Logistic regression analysis of important variables.

\begin{tabular}{|c|c|c|c|c|c|c|c|c|c|}
\hline \multicolumn{10}{|c|}{ Variables in the Equation } \\
\hline & & \multirow[b]{2}{*}{ B } & \multirow{2}{*}{ S.E. } & \multirow[b]{2}{*}{ Wald } & \multirow[b]{2}{*}{$\mathrm{df}$} & \multirow[b]{2}{*}{ Sig. } & \multirow[b]{2}{*}{$\operatorname{Exp}(B)$} & \multicolumn{2}{|c|}{ 95\% C.I. for $\operatorname{EXP}(B)$} \\
\hline & & & & & & & & Lower & Upper \\
\hline & education qualification & & & 5.501 & 4 & 0.240 & & & \\
\hline & education qualification (1) & -1.438 & 1.129 & 1.622 & 1 & 0.203 & 0.237 & 0.026 & 2.170 \\
\hline & education qualification (2) & -0.520 & 1.100 & 0.224 & 1 & 0.636 & 0.594 & 0.069 & 5.134 \\
\hline & education qualification (3) & -0.666 & 1.114 & 0.358 & 1 & 0.550 & 0.514 & 0.058 & 4.557 \\
\hline & education qualification (4) & -1.141 & 1.106 & 1.064 & 1 & 0.302 & 0.320 & 0.037 & 2.793 \\
\hline \multirow[t]{6}{*}{ Step $1^{\mathrm{a}}$} & children taken by caesarian & -0.330 & 0.576 & 0.329 & 1 & 0.566 & 0.719 & 0.232 & 2.223 \\
\hline & place of caesarian delivery (1) & -0.480 & 0.331 & 2.106 & 1 & 0.147 & 0.619 & 0.324 & 1.183 \\
\hline & how many children do you have & -0.185 & 0.514 & 0.129 & 1 & 0.719 & 0.831 & 0.304 & 2.275 \\
\hline & family income per month & 0.184 & 0.147 & 1.565 & 1 & 0.211 & 1.202 & 0.901 & 1.604 \\
\hline & cost of caesarian & -0.625 & 0.287 & 4.761 & 1 & 0.029 & 0.535 & 0.305 & 0.938 \\
\hline & Constant & 3.590 & 1.376 & 6.805 & 1 & 0.009 & 36.238 & & \\
\hline
\end{tabular}

${ }^{a}$ Variable(s) entered on step 1: education qualification, children taken by caesarian, place of caesarian delivery, how many children do you have, family income per month, cost of caesarian.

Table 12. Meta analysis of number of cesarean delivery baby on locality and education level.

\begin{tabular}{ccccccc}
\hline & \multicolumn{5}{c}{ Locality } \\
\hline & \multicolumn{7}{c}{ Urban } & \multicolumn{3}{c}{ Rural } \\
\hline \multicolumn{7}{c}{ Number of cesarean baby } \\
\hline Level of education & $0-2$ & $3-4$ & Total & $0-2$ & $3-4$ & Total \\
\hline Illiterate & 2.89 & 0.11 & 03 & 10.04 & 0.96 & 11 \\
Primary & 12.52 & 0.48 & 13 & 16.43 & 1.57 & 18 \\
Secondary & 31.79 & 1.21 & 33 & 53.85 & 5.15 & 59 \\
Higher secondary & 32.75 & 1.25 & 34 & 34.69 & 3.13 & 38 \\
Graduated & 25.05 & 0.95 & 26 & 41.99 & 4.01 & 46 \\
Total & 105 & 04 & 109 & 157 & 15 & 172 \\
\hline
\end{tabular}




$$
x^{2}=\sum \sum \frac{O_{i j}^{2}}{E_{i j}}-n
$$

For urban area:

$$
\begin{aligned}
x_{1}^{2} & =\frac{3^{2}}{2.89}+\frac{0^{2}}{0.11}+\frac{0^{2}}{0}+\frac{13^{2}}{12.52}+\frac{0^{2}}{0.48}+\frac{31^{2}}{31.79}+\frac{2^{2}}{1.21}+\frac{33^{2}}{32.75}+\frac{1^{2}}{1.25}+\frac{25^{2}}{25.05}+\frac{1^{2}}{0.95}-109 \\
& =110.1982693-109 \\
& =1.198\left(P \text { value, } P_{1}=0.878428\right)
\end{aligned}
$$

The result is not significant at $P<0.05$.

As $P_{1}=0.878428>0.05$ so $\mathrm{H}_{0}$ is accepted.

For rural area:

$$
\begin{aligned}
x_{2}^{2} & =\frac{10^{2}}{10.04}+\frac{1^{2}}{0.96}+\frac{16^{2}}{16.43}+\frac{2^{2}}{1.57}+\frac{56^{2}}{53.85}+\frac{3^{2}}{5.15}+\frac{36^{2}}{34.69}+\frac{2^{2}}{3.31}+\frac{39^{2}}{41.99}+\frac{7^{2}}{4.01}-172 \\
& =4.125\left(P \text { value, } P_{2}=0.389353\right)
\end{aligned}
$$

The result is not significant at $P<0.05$.

AS $P_{2}=0.389353>0.05$ so accept $\mathrm{H}_{0}$.

For conclusion using data of all location meta analysis can be performed by combining the $P$ values of $x^{2}$ where combined $P$ value is given by-

$$
\begin{aligned}
-2 \ln P & =-2 \ln \left(P_{1}+P_{2}\right) \\
& =-2 \ln (0.878428 * 0.389353) \\
& =-2 \ln (0.3420185771) \\
& =2.146
\end{aligned}
$$

Thus $-2 \ln P$ is distributed as $x^{2}$ with $2 K=(2 \times 2)(2$ location so $K=2)$ df. The tabulated value of $x^{2}$ at $5 \%$ level of significance with $4 \mathrm{df}$ is 9.49 which is greater than $x^{2} \quad(-2 \ln P)$. So $\mathrm{H}_{0}$ is accepted.

The calculation can also be done by combining the values of calculated $x^{2}$ for urban and rural areas where combined $x^{2}$ is

$$
\begin{aligned}
x^{2} & =x_{1}^{2}+x_{2}^{2} \\
& =1.198+4.125 \\
& =5.323
\end{aligned}
$$

This $x^{2}$ has $(4+4)=8 \mathrm{df}$, the tabulated value at $5 \%$ level of significance is 15.51 which are greater than combined $x^{2}$ so $\mathrm{H}_{0}$ is accepted.

So this indicates that number of cesarean delivery baby is independent of locality and education level.

\section{Conclusion}

A caesarian section is a surgical delivery of a baby that involves making incisions in the mother's abnormal wall and uterus. The purpose of the study is to provide a certain reference for the future pregnant women in Bangladesh. The study mainly focuses on the pattern of caesarian and normal delivery of childbirth in Bangladesh and the relationship between parent's educational qualification and nature of childbirth. We found that about $80.4 \%$ of women recommend normal 
delivery for the next gradations. So that the significant finding is to make a decision for the policy maker where they can have initiative to ensure normal delivery in all kinds of clinic (Government and Private) in Bangladesh. Moreover, the physical condition of the pregnant woman is not considered when analyzing the factors affecting caesarean section and normal delivery.

\section{Acknowledgements}

We are giving special thanks to the students of the first year, Department of Statistics, Noakhali Science and Technology University. They can support us to collect the primary data from the field operation. We would like to thank the research cell, Noakhali Science and Technology University for funding to complete this research.

\section{Conflicts of Interest}

The authors declare no conflicts of interest.

\section{References}

[1] Wondie, A.G., Zeleke, A.A., Yenus, H. and Tessema, G.A. (2019) Cesarean Delivery among Women Who Gave Birth in Dessie Town Hospitals. Northeast Ethiopia. PLOS ONE, 14, e0216344.

[2] Parvej, Md.I., Tabassum, M. and Aktar, N. (2021) Preferences between Caesarean Section and Normal Vaginal Delivery among the Reproductive Women in Bangladesh. Journal of Applied Science, Engineering, Technology, and Education, 3, 82-89. https://doi.org/10.35877/454RI.asci152

[3] Rahman, M., Shariff, A.A., Shafie, A., Saaid, R. and Tahir, R.Md. (2015) Caesarean Delivery and Its Correlates in Northern Region of Bangladesh: Application of Logistic Regression and Cox Proportional Hazard Mode. Journal of Health, Population and Nutrition, 33, 8. https://doi.org/10.1186/s41043-015-0020-2

[4] Khan, M.N., Islam, M.M., Shariff, A.A., Alam, M.M. and Rahman, M.M. (2017) Socio-Demographic Predictors and Average Annual Rates of Caesarean Section in Bangladesh between 2004 and 2014. PLOS ONE, 12, e0177579.

[5] Caesarean Section. https://en.wikipedia.org/wiki/Caesarean section

[6] Rahman, M.M. (2018) Determinants of Caesarean Section in Bangladesh: CrossSectional Analysis of Bangladesh Demographic and Health Survey 2014 Data. PLoS ONE, 13, e0202879. https://doi.org/10.1371/journal.pone.0202879

[7] Khandoker, M., Joy, S.B., Das, S.K. and Biswas, A.K. (2020) Comparative Study on Fetomaternal Outcome after Lower Uterine Segment Caesarean Section and Vaginal Delivery in Eclamptic Patient. Faridpur Medical College Journal, 15, 16-20. https://doi.org/10.3329/fmcj.v15i1.49002

[8] Baizid, L.A.R. (2020) Community Clinics in Bangladesh: A Unique Example of Public-Private Partnership. Heliyon, 6, e03950.

[9] Nahar, S. and Costello, A. (1998) The Hidden Cost of Free Maternity Care in Dhaka, Bangladesh. Health Policy and Planning, 4, 417-422. https://doi.org/10.1093/heapol/13.4.417

[10] Save the Children (2019) Bangladesh: 51 Percent Increase in "Unnecessary" C-Section 
in Two Years.

https://www.savethechildren.net/news/bangladesh-51-cent-increase- $\% \mathrm{E} 2 \% 80 \% 9 \mathrm{Cu}$ nnecessary\%E2\%80\%9D-c-sections-two-years 